\title{
HIGHER EDUCATION INSTITUTIONS' IMPACT ON THE ECONOMY
}

\author{
Agnė VAICIUKEVIČIŪTE் ${ }^{1}$, Jelena STANKEVIČIENE ${ }^{2}$, \\ Nomeda BRATČIKOVIENE் ${ }^{3}$ \\ 1, ${ }^{2}$ Faculty of Business Management, Vilnius Gediminas Technical University, Lithuania \\ ${ }^{3}$ Faculty of Fundamental Sciences, Vilnius Gediminas Technical University, Lithuania
}

Received 18 November 2018; accepted 17 April 2019

\begin{abstract}
Despite the strong public interest in the accountability and efficiency in education spending on higher education institutions (HEIs) in Lithuania, there are currently no existing studies which have examined the impact of HEIs on the country's economy. In the present study, we have used a disaggregated input-output table for Lithuania's tertiary education institutions in order to determine the output value added to the local economy by the presence of HEIs. The results of the study have revealed that HEIs contribute to the Lithuanian economy in the period of (2010-2016), with the average of gross domestic output (GDP) of $298,48 \mathrm{mln}$. euros. The present study is the first of its kind to use input-output table evaluate the impact of HEIs on Lithuania's economy, and its results could be of significant value to the current policy debates regarding the status of higher education in Lithuania.
\end{abstract}

Keywords: Higher education institutions (HEIs), economic impact, input-output analysis, universities, Lithuania.

JEL Classification: G32, O32, O34.

\section{Introduction}

In the educational context, it is increasingly important that higher education institutions (HEIs) are demonstrably efficient and yield a positive economic impact upon their environment and key stakeholders (ECD, 2013; Jaeger \& Kopper, 2014; Zhang, Larkin, \& Lucey, 2017; Tilak, 2018). Three main reasons for this trend emerge from the literature. First, the global needs are increasingly pressing. As pointed out by the Organisation for Economic Co-operation and Development (OECD) (2013), problems such as climate change, food insecurity, and inclusive growth can only be tackled by a highly skilled workforce. Similarly, job creation, innovation and wage growth are necessary precursors to a rapidly developing economy. Secondly, concomitant with the rapid industrialisation and growth of the emerg-

*Corresponding author. E-mail: jelena.stankeviciene@vgtu.lt 
ing and developing economies, demand for HE among traditionally marginalised cohorts is increasing. There is, therefore, greater demand for quality higher education than ever before. Finally, while the demand for $\mathrm{HE}$ is growing, available resources that drive quality HE, such as land, infrastructure and financial capital, are shrinking creating the requirement to achieve greater outcomes with limited inputs.

The impact of HEIs on the local economy is heavily influenced by the nature of the institution itself. More specifically, it is influenced by the HEI's purpose and funding sources (Hermannsson, Lisenkova, McGregor, \& Swales, 2010, 2013, 2015; Zhang, Larkin, \& Lucey, 2017). HEIs vary widely in their principal income sources. Institutions may be supported by research funding, contracts, and collaborations with businesses, and/or tuition fees, but a large number of HEIs are also supported by government funds composed of the contributions of local citizens (Lepori, Benninghoff, Jonbloed, Salerno, \& Slipersaeter, 2007). Given that many of higher education organisations receive public funding as a primary source of their income, they are subject to public scrutiny and accountability (Daniunas, Kliukas, Prentkovskis, \& Ulinskaite, 2013; Viaene \& Zilcha, 2013; Kaiser, Vossensteyn, \& Koelman, 2001).

An assessment of the economic impact of HEIs is particularly important for institutions in Lithuania. The country's limited educational funding has created uncertainty about the quality of the education delivered at public HEIs. Low salaries for researchers and professors of Lithuanian universities have led to massive emigration of highly-skilled researchers who are unable to support themselves (MacDonald, 2010; Yudkevich, Altbach, \& Rumbley, 2017). Similarly, the loss of qualified instructors has been followed by an attrition of the country's brightest students, who leave in favour of foreign HEIs and never return home (Daniunas et al., 2013). The loss of talent is further compounded by issues with quality control (Legcevic \& Hecimovic, 2016). These issues demonstrate the need to understand the economic impact and the value of HEIs on the economy of Lithuania. The present study is aimed to examine the input-output value of Lithuanian HEIs on the local economy.

Problem statement. HEIs in Lithuania have a strong public interest in understanding their economic value. In Lithuania, public HEIs receive support from the state via partially- or fully-funded places for students that are comprised of financial contributions from Lithuanian citizens. Meanwhile, private institutions rely more heavily on tuition fees, research grants, and business contracts. Despite the availability of funding sources, there remains wide emigration of highly-skilled researchers and professors away from local HEIs, creating uncertainty about the educational value of these institutions. As a result, there is a strong public interest for accountability and efficiency in education spending on higher education institutions in Lithuania, and a need to understand the value they bring to the local economy.

The purpose of this research is to examine the economic impact of HEIs on the local economy of Lithuania. The study will use Leontief's (1936) input-output modelling approach to examine the HE sector as a disaggregated and a modelled industry. The primary focus of this study will be on analysing the income and expenditure characteristics that influence HE regional impacts. Output multipliers will be used to calculate each HEI's impact on the economy. 
Significance of the study. So far, very few studies have been conducted with a focus on Eastern European countries (Fotea \& Gutu, 2016). More importantly, none of these studies have specifically examined the HE sector in Lithuania. Secondly, many of the previous research studies produced abnormal results due to the application of measurement methods that duplicated the economic impact of supply-side HEI effects. These two problems demonstrate that there remains a gap in the research literature regarding the economic impact of Lithuanian HEIs.

Results of the research examined the economic impact of HEIs, specifically on the economy of Lithuania. This unique focus provides valuable insights for stakeholders along the value chain of higher education by providing a measure of accountability on whether these contributions are providing significant value and a return on investment. The findings identified the output value added to the local economy as a result of the HEIs' presence in the region.

\section{The importance of evaluating HEIs from an economic perspective}

Economic impact studies have a long history in the education sector. Given that most of these studies are concerned with empirics, it is unsurprising that attention has largely been paid to the methodological processes used to conduct impact studies, with debate raging about the inputs and outputs to include.

It is increasingly recognised that higher education, the tertiary sector of education, is vital to the economic competitiveness of both regions and nations in the context of a global economy that is increasingly knowledge-driven (Zhang, Larkin, \& Lucee, 2017). Researchers, and especially those working within the context of economic development, have, however, pointed out that until fairly recently, attention was focused on the economic returns generated by primary and secondary sectors of education, with higher education considered to yield relatively lower returns, both in economic and social terms (Yusuf, 2007; Jaeger \& Kopper, 2014; Tilak, 2018).

More recently, however, the importance of higher education to broader economic objectives has been recognised by policymakers and researchers alike (Brennan et al., 2018b). Evaluation of the economic impact of HEIs is undertaken through economic impact assessments. There are two type of assessments /evaluations that are performed globally - performance assessment and impact assessment/or evaluation. Their differences depend on the purpose, evaluation questions, and design that is applied (World Bank Group, 2016).

Impact assessment is able to serves different purposes - to inform the policy - and decision-makers about potential economic, social or environmental consequences, to improve transparency, to increase public participation and improve the legitimacy of proposed policies, to show and indicate how public policies aim to achieve envisioned goals using the palette of various indicators, and finally, to contribute to continuous learning in policy development by identifying causalities that inform ex-post review of policies (Deininger \& Byerlee, 2011).

Selection of method or methods for assessment should principally consider the appropriateness of the evaluation design for answering the main evaluation questions as well as balance cost, feasibility, and the level of rigor needed to inform specific decisions. Usually, 
assessments use methods that generate the highest-quality and most credible evidence that corresponds to the questions being asked, taking into consideration time, budget, and other practical considerations. A combination of qualitative and quantitative methods applied in a systematic and structured way yields valuable findings and is often optimal, regardless of evaluation design. Impact evaluations must use experimental methods (randomisation) or quasi-experimental methods and may supplement these with other qualitative or quantitative methods to increase understanding of how or why an intervention achieved or did not achieve the expected impact.

There are several types of impact assessments based on their scope (for example, global vs. local), level (policy impact assessment), strategic aim (environmental assessment, for example), orientation (project related assessments), or topic (education, or high education sector, cold be considered as such) (Deininger \& Byerlee, 2011). Although there is no existing consensus on the precise economic yields generated by institutions of higher education, nor on the factors that moderate and mediate relationships between inputs and outputs, generally speaking, the literature in this area focuses on three major impacts: short-term expenditure effects, knowledge and human capital based effects and (long-term) value creation effects and knowledge spill over effects (see Table 1 for a summary of how different authors conceptualise economic impact).

Many of the studies that are reviewed do not disaggregate fully between these effects and instead, consider them as complex dynamics arising from the presence and activities of universities and colleges. Nevertheless, for the purposes of this literature review, it is useful to focus on short-term expenditure.

Table 1. Conceptualising economic impact (source: compiled by authors)

\begin{tabular}{|l|l|l|}
\hline Conceptualisation & \multicolumn{1}{|c|}{ Definition } & \multicolumn{1}{|c|}{ Main authors } \\
\hline $\begin{array}{l}\text { Short-term } \\
\text { expenditure effects }\end{array}$ & $\begin{array}{l}\text { The direct, or first order } \\
\text { effects that can be directly } \\
\text { attributed to the presence } \\
\text { and activities of institutes of } \\
\text { higher education }\end{array}$ & $\begin{array}{l}\text { Borralho, Feria, and Lopes, 2015; Kotosz, } \\
\text { Gaunard-Anderson, and Lukovics, 2018; } \\
\text { Elliot, Levin, and Mesisel, 1988; Huggins } \\
\text { and Cooke, 1997; Siegfried, Sanderson, and } \\
\text { McHenry, 2007; Thanki, 1999; Goddard and } \\
\text { Vallance, 2013; Harris, 1997; Forrant, 2001 }\end{array}$ \\
\hline $\begin{array}{l}\text { Long-term value } \\
\text { creation effects }\end{array}$ & $\begin{array}{l}\text { The long-term effects that } \\
\text { accrue from the generation } \\
\text { of knowledge and which } \\
\text { have implications for the } \\
\text { supply side, and economic } \\
\text { growth }\end{array}$ & $\begin{array}{l}\text { Garrido-Yserte and Gallo-Rivera, 2010; } \\
\text { Psacharopoulos and Patrinos, 2002; Florax, } \\
\text { 1992; Borralho et al., 2015; Goldstein and } \\
\text { Renault, 2004; Siegfried et al., 2007; Stokes } \\
\text { and Coornes, 1998; Huggins and Cooke, } \\
\text { 1997; Huggins and Johnston, 2009; Huggins, } \\
\text { Johnston, and Thompson, 2012; Johansen and } \\
\text { Arano, 2016; Barra and Zotti, 2017 }\end{array}$ \\
\hline $\begin{array}{l}\text { Knowledge spill } \\
\text { over effects }\end{array}$ & $\begin{array}{l}\text { The effects that are produced } \\
\text { from the exploitation of } \\
\text { the outcomes of academic } \\
\text { research and the engagement } \\
\text { in knowledge exchange with } \\
\text { research, commercial and } \\
\text { corporate partners }\end{array}$ & $\begin{array}{l}\text { Cox and Taylor, 2006; Yusuf, 2007; Guerrero, } \\
\text { Cunningham, and Urbano, 2015; Uyarra, } \\
\text { 2010; Jaeger and Kopper, 2014; Goldstein and } \\
\text { Renault, 2004; Jaeger and Kopper, 2014 }\end{array}$ \\
\hline
\end{tabular}


Short-term, first-order effects of HEIs. One of the most straightforward means of assessing the economic impact of HEIs is by examining the direct, or first-order effects that can be directly attributed to their presence and activities (Kotosz, Gaunard-Anderson, \& Lukovics, 2018). Of the considerable outputs that universities, and especially large public universities produce, it is employment that is most commonly considered by researchers (Elliot, Levin, \& Mesisel, 1988; Huggins \& Cooke, 1997; Siegfried, Sanderson, \& McHenry, 2007; Thanki, 1999; Goddard \& Vallance, 2013; Harris, 1997; Forrant, 2001). Universities are typically large employers, especially in urban and suburban areas (Jaeger \& Kopper, 2014; Goddard \& Vallance, 2013). Through their very presence, and importantly, through their expansion (which, in turn, is generated through income generation and other activities), universities and colleges, therefore, make an important contribution to the local employment market. Furthermore, jobs are created through expenditure effects, whereby HEI procurement activities extend job creation to third sectors (Ciccone \& Peri, 2006).

Although job creation is considered here to be a short-term, first-order effect, more complex models have demonstrated the longer-term effects that HEIs have upon employment. In addition to hiring faculty, staff and other key personnel, universities and colleges, through their very raison d'être boost the employability of their students, with long-term employment enhancing effects (Borralho, Feria, \& Lopes, 2015). Many of the empirical papers have alluded to these long-term direct effects, but as pointed out by Stokes and Coornes (1998) in reality, it is difficult to estimate those effects with any accuracy (see also Moretti, 2004; Pastor, Pérez, \& De Guevara, 2013).

Consumption effects are also related to university expenditures effects (Zhang, Larkin, \& Lucey, 2017b). Through the disbursement of wages and expenditures, HEIs are said to exert a positive effect on local and regional consumption levels - a key factor of growth (Jaeger \& Kopper, 2014). In addition, the presence of the student population itself can also spur economic growth through the demand side effects propagated by consumption (Beck, Elliott, Meisel, \& Wagner, 1995; Siegfried et al., 2007; Carroll \& Smith, 2006). This seems to be especially true of urban colleges with significant urban populations of students (Steinacker, 2005). The side effects of demand could have long-term, positive implications for employment levels, causing dynamic and non-linear outcomes. Furthermore, it has been demonstrated that a significant student population has the ability to spur sustainable regional development, given students' high consumption propensities (Carroll \& Smith, 2006). This effect could compensate for any crowding out effects of student acquisition of local jobs.

Finally, there are demand effects caused by the investment undertaken by the HEI, which can yield significant effects in terms of local value (Huggins \& Cooke, 1997; Power \& Malmberg, 2008; Drucker, 2016). With regards to regional development, the investment of colleges and universities in local infrastructure (e.g., buildings and transportation links) and communities should be expected to trigger demand and thereby, wider multiplier effects. As a demanding customer, the HEI could also generate further positive supply side effects over the short- to mediumterm (Drucker, 2016). 
Table 2. Summary of the conclusions of studies on the first-order effects of HEIs (source: compiled by authors)

\begin{tabular}{|l|l|}
\hline \multicolumn{1}{|c|}{ Major Finding } & \multicolumn{1}{c|}{ Authors } \\
\hline $\begin{array}{l}\text { Through their activities and existence (e.g. } \\
\text { hiring practices) universities and colleges } \\
\text { make an important contribution to the local } \\
\text { employment market for HEI staff. }\end{array}$ & $\begin{array}{l}\text { Jaeger and Kopper, 2014; Elliot, Levin, and Mesisel, } \\
\text { 1988; Huggins and Cooke, 1997; Siegfried, San- } \\
\text { derson, and McHenry, 2007; Thanki, 1999; Goddard } \\
\text { and Vallance, 2013; Harris, 1997; Forrant, 2001 }\end{array}$ \\
\hline $\begin{array}{l}\text { Universities and colleges boost employment } \\
\text { in third sectors through procurement } \\
\text { activities }\end{array}$ & Ciccone and Peri, 2006 \\
\hline $\begin{array}{l}\text { Universities and colleges enhance the } \\
\text { employability prospects of graduates } \\
\text { through upskilling }\end{array}$ & Borralho, Feria, and Lopes, 2015 \\
\hline $\begin{array}{l}\text { The employment and employability } \\
\text { enhancing effects of universities and } \\
\text { colleges depends on the extent to which the } \\
\text { local economy is already developed }\end{array}$ & $\begin{array}{l}\text { Psacharopoulos and Patrinos, 2002; Moretti, 2004; } \\
\text { Yen, Ong, and Ooi, 2015 }\end{array}$ \\
\hline $\begin{array}{l}\text { Through expenditures and the disbursement } \\
\text { of wages salaries, HEIs have a positive effect } \\
\text { on local and regional consumption levels }\end{array}$ & Zhang, Larkin, and Lucey, 2017; Jaeger and Kopper, \\
\hline $\begin{array}{l}\text { Universities and colleges help to spur local } \\
\text { economic growth through the consumption } \\
\text { activities of student populations }\end{array}$ & $\begin{array}{l}\text { Beck, Elliott, Meisel, and Wagner, 1995; Steinacker, } \\
\text { 2005; Siegfried et al., 2007; Carroll and Smith, 2006 }\end{array}$ \\
\hline $\begin{array}{l}\text { Investments and expenditures undertaken } \\
\text { by the HEI produce positive demand effects }\end{array}$ & $\begin{array}{l}\text { Huggins and Cooke, 1997; Power and Malmberg, } \\
\text { 2008; Drucker, 2016 }\end{array}$ \\
\hline
\end{tabular}

To summarise this section, several authors have adopted an approach to economic impact that places emphasis on the direct effects that can be directly attributed to the work, presence and activities of HEIs. This is the most straightforward approach to measuring economic impact. These studies have focused their attention on outcomes such as job creation, overall employment levels, consumption effects and demand effects (see Table 2). Typically, a shortterm timeframe is adopted, and the focus is on long-term value, although some of the more sophisticated forms of analyses are conducted over a longer time frame, and consider a wider environmental impact.

\section{Input-Output modelling to measure economic impact of HEIs}

The HEI are considered to represent a separate sector or branch of industry, and researchers and analysts have used the I-O method to examine their financial structure, expenditures and effects on other segments of national economy, or on the economy as a whole. For more than 15 years, the I-O model has been used to analyse the HEI. In such an approach, the model has been upgraded to construct an HEI-disaggregated I-O table, in which each HEI represents a separate sector (Hermannsson \& Swales, 2010).

There are a number of studies taking into account the impact of HEI on regional and/or national economies (Drucker \& Goldstein, 2007; McGregor, Swales, \& McLellan, 2006; Siegfried, Sanderson, \& McHenry, 2007; Drucker, 2016). These studies considered demand-side 
and universities as any other business and which students are treated as tourists, a source of consumption spending for the local economy (Hermannsson et al., 2010, 2013, 2015). Besides academic studies, there are studies conducted by different think tanks and research institutions, but are rather criticised for a relaxed methodological approach (Siegfried et al., 2007).

HEIs are diverse when it comes to their scale and nature; some are focused on specific research, while others are student-driven and/or connected with the market in search for a more sustainable business model, making them less dependent on the public funds. This affects HEIs' type and amount of revenues, which vary from funding councils, tuition fees, public money, research grants, commercial contracts and charities (Hermansson et al., 2015). On the other hand, universities generate a wide range of benefits, posing an impact on economy, society, and entire cultural environment of one country or the region (Glasson et al. 2003; Huggins \& Johnson, 2009; Goddart \& Vallance, 2013). But, as indicated by Zhang et al. (2017), a "narrow economic focus on the impact of higher education is partial and incomplete". These researchers agree with many other authors (McHenry, Sanderson, \& Siegfried, 2012; Pastor, Perez, \& de Guevara, 2013), who all claim that "universities have significant downstream effects on the society and economy from skill enhancement, which are both empirically and conceptually difficult to measure" (Zhang et al., 2017).

When constructing tables, authors usually employ typical methodology that assumes two types of spending - exogenous and endogenous. Exogenous refers to governments spending, exports and investment, and has been considered as independent from the level of economic activity within the host economy. On the other hand, endogenous spending has been determined by the overall level of economic activity within the host economy or within the institutions as a reaction to shocks to the sectors. Additionally, demand for intermediate inputs and sometimes, household consumption demands, are considered to be endogenous. The key assumption of the I-O model is that the system, such as the HEI, is demand-determined, and not supply-determined (Zhang et al., 2017). Assuming that exogenous expenditure determines the endogenous activities, multipliers can be derived.

The central part of I-O analysis involves input-output tables. Each table includes very specific, sector-related data that are sorted in columns and rows. For example, column 'entries' usually indicates inputs to specific industrial sector, and rows stand for a given sector. This format clearly indicates inter-dependency of different sectors and enables the analysis and estimations in a clearer way. Additionally, specific industries are listed or indicated in the headers of each row and column. For example, OECD uses I-O tables that present matrices of inter-industrial flows of goods and services (produced domestically and imported) in current prices (USD million), for all OECD countries and 27 non-member economies (OECD, 2018).

This section proposes using multipliers in Input-Output (I-O) models as a measure for evaluating economic impacts of HEIs.

We consider each HEI as a sector in the national economy. Suppose we have $n$ HEIs $\left\{H_{1}, H_{2}, \ldots, H_{n}\right\}$ and are considering the impact of $H_{-} i$ for some $i \in\{1,2, \ldots, n\}$. Other sectors (including other HEIs) are considered as $S_{1}, S_{2}, \ldots, S_{m}$. The computation of the economic impact of $H_{i}$ is carried out through the following three steps:

- Construct the I-O table. 
- Compute the Leontief inverse matrix.

- Derive the output multiplier.

Constructing the I-O table. Table 3 illustrates the I-O table. In the table, while each row represents the distribution of the output (income) that each sector gives to the other sectors, each column describes the distribution of the input (expenditure) that each sector receives from other sectors.

Consider the rows, for example, the institute $H_{1}$ would distribute its total output $O_{1}$ as:

$$
\begin{gathered}
X_{11} \text { for } H_{1} \text { (itself), } \\
X_{1 n} \text { for } H_{n}, \\
X_{1(n+1)} \text { for } S_{1}, \\
X_{1(n+m)} \text { for } S_{m} \text {, and }
\end{gathered}
$$

$F_{1}$ as the exogenous output (final demand) such as consumption, investment, government expenditure, or exports.

As a result, the following formula holds:

$$
O_{1}=X_{11}+\ldots+X_{1 n}+X_{1(n+1)}+\ldots+X_{1(n+m)}+F_{1} .
$$

More generally, for each $j=1, \ldots, n+m$, the following equation holds:

$$
O_{j}=X_{j 1}+\ldots+X_{j n}+X_{j(n+1)}+\ldots+X_{j(n+m)}+F_{j} .
$$

Consider the columns, for example, the institute $H_{1}$ would receives as its input total amount of $O_{1}$, in which:

$$
X_{11} \text { is from } H_{1} \text {, }
$$

Table 3. I-O table of HEIs and other economic sectors (source: compiled by authors)

\begin{tabular}{|c|c|c|c|c|c|c|c|c|}
\hline & $H_{1}$ & $\ldots$ & $H_{n}$ & $S_{1}$ & $\ldots$ & $S_{m}$ & Final Demand & Total \\
\hline$H_{1}$ & $X_{11}$ & $\ldots$ & $X_{1 n}$ & $X_{1(n+1)}$ & $\ldots$ & $X_{1(n+m)}$ & $F_{1}$ & $O_{1}$ \\
\hline$\ldots$ & $\ldots$ & $\ldots$ & $\ldots$ & $\ldots$ & $\ldots$ & $\ldots$ & $\ldots$ & $\ldots$ \\
\hline $\mathrm{H}_{n}$ & $X_{n 1}$ & $\ldots$ & $X_{n n}$ & $X_{n(n+1)}$ & $\ldots$ & $X_{n(n+m)}$ & $F_{n}$ & $O_{n}$ \\
\hline$S_{1}$ & $X_{(n+1) 1}$ & $\ldots$ & $X_{(n+1) n}$ & $X_{(n+1)(n+1)}$ & $\ldots$ & $X_{(n+1)(n+m)}$ & $F_{n+1}$ & $O_{n+1}$ \\
\hline$\ldots$ & $\ldots$ & $\ldots$ & $\ldots$ & $\ldots$ & $\ldots$ & $\ldots$ & $\ldots$ & $\ldots$ \\
\hline$S_{m}$ & $X_{(n+m) 1}$ & $\ldots$ & $X_{(n+m) n}$ & $X_{(n+m)(n+1)}$ & $\ldots$ & $X_{(n+m)(n+m)}$ & $F_{n+m}$ & $O_{n+m}$ \\
\hline $\begin{array}{c}\text { Other } \\
\text { sources }\end{array}$ & $Y_{1}$ & $\ldots$ & $Y_{n}$ & $Y_{n+1}$ & $\ldots$ & $Y_{n+m}$ & $Y_{n+m+1}=F_{n+m+1}$ & $O_{n+m+1}$ \\
\hline Total & $O_{1}$ & $\ldots$ & $O_{n}$ & $O_{n+1}$ & $\ldots$ & $O_{n+m}$ & $O_{n+m+1}$ & $O_{s}$ \\
\hline
\end{tabular}




$$
\begin{gathered}
X_{n 1} \text { is from } H_{n}, \\
X_{(n+1) 1} \text { is from } S_{1},
\end{gathered}
$$

$Y_{1}$ is from other sources such as imports, labour, and capital.

It should be noted that the total of input and output for each sector are the same. As a consequence, we have the following equation:

$$
O_{1}=X_{11}+\ldots+X_{n 1}+X_{(n+1) 1}+\ldots+X_{(n+m) 1}+Y_{1} .
$$

Or more generally, for each $j=1, \ldots, n+m$, the following equation holds:

$$
O_{j}=X_{1 j}+\ldots+X_{n j}+X_{(n+1) j}+\ldots+X_{(n+m) j}+Y_{j} .
$$

Finally, the total amount of input and output for all sectors are the same, and is denoted as $O$ in the table.

$$
O_{s}=O_{1}+\ldots+O_{n}+O_{n+1}+\ldots+O_{n+m}+\ldots+O_{n+m+1} .
$$

Computing the Leontief inverse matrix. Given the I-O table, we have the following relation:

$$
X\left[\begin{array}{c}
1 \\
\cdots \\
1
\end{array}\right]+F=O
$$

where

$$
\begin{gathered}
X=\left(\begin{array}{ccc}
X_{11} & \cdots & X_{1(n+m)} \\
\vdots & \ddots & \vdots \\
X_{(n+m) 1} & \cdots & X_{(n+m)(n+m)}
\end{array}\right) ; \\
F=\left[\begin{array}{c}
F_{1} \\
\cdots \\
F_{n+m}
\end{array}\right] ; \\
O=\left[\begin{array}{c}
O_{1} \\
\cdots \\
O_{n+m}
\end{array}\right] .
\end{gathered}
$$

Consider the matrix $\mathbf{A}$ as following:

$$
\mathbf{A}=\left(\begin{array}{ccc}
X_{11} / O_{1} & \cdots & X_{1(n+m)} / O_{n+m} \\
\vdots & \ddots & \vdots \\
X_{(n+m) 1} / O_{1} & \cdots & X_{(n+m)(n+m)} / O_{n+m}
\end{array}\right)
$$

Then, we have

$$
\mathbf{A} O+F=O
$$

The formula is equivalent to

$$
F=O-\mathbf{A} O
$$


or

$$
F=(I-\mathbf{A}) O .
$$

Multiplying the inverse of $(I-\mathbf{A})$ results in the following equation:

$$
O=(I-\mathbf{A})^{-1} F \text {. }
$$

Here $(I-\mathbf{A})^{-1}$ is called the Leontief inverse matrix.

Deriving the output multiplier. The output multipliers are derived from the above for-

mula. Specifically, the $\left((I-\mathbf{A})^{-1}\right)^{T}\left[\begin{array}{c}1 \\ \ldots \\ 1\end{array}\right]$ defines the output multipliers for $\left[\begin{array}{c}H_{1} \\ \ldots \\ H_{n} \\ S_{1} \\ \ldots \\ S_{m}\end{array}\right]$. The intuition of the output multipliers is that they reflect how much the total economic output will change with respect to a unit change in final demand for the corresponding sector. As a result, such output multipliers are used as an estimation for the national economic impact of sectors (here, we are interested in HEIs).

Construction of an HEI-disaggregated Input-Output table. As mentioned above, in order to evaluate the national economic of HEIs, we consider each HEI as a separate sector and thus, it is necessary to construct the I-O table for the new sectors (HEIs and old sectors). This type of table is referred to as HEI-disaggregated I-O table. An essential task is to separate out the HEIs from the "Education Service" sector as a whole from the National Accounts. The disaggregation proceeds in two steps:

- First, we disaggregate the "Education Service" sector in the national table into a HEI sector and a residual education sector.

- Second, we further disaggregate the HEI sector into individual institution.

As a result, we have an augmented I-O table as the basis for our analysis. The rest of this section describes how the methods used for constructing the rows and columns of such an augmented I-O table. Table 4 describes the data sourced in creating a separate column for each HEI.

Table 4. Summary of HEI columns (source: compiled by authors)

\begin{tabular}{|l|l|}
\hline & \multicolumn{1}{|c|}{$\begin{array}{c}\text { Individually determined/Proxied by assuming ratios for the } \\
\text { university sector }\end{array}$} \\
\hline Total expenditure & $\begin{array}{l}\text { Universities Official Financial Activities Reports (OFAR), State } \\
\text { Enterprise Centre of Registers }\end{array}$ \\
\hline Imports & Lithuanian Public Procurement Office \\
\hline Operating surplus & Input-Output Table for Lithuania 2010 (last time adjusted 2015) \\
\hline Compensation of employees & Universities Official Financial Activities Reports \\
\hline Product taxes less subsidies & Input-Output Table for Lithuania 2010 (last time adjusted 2015) \\
\hline Intermediate expenditures & Input-Output Table for Lithuania 2010 (last time adjusted 2015) \\
\hline
\end{tabular}


In Table 4, imports consist of supplier information, i.e., goods and services purchased by HEIs. Operating surplus and product taxes less subsidies were determined for each HEI as the same proportion of overall expenditure as in the education service sector as a whole.

In an input-output table, a row reveals the total income of a sector and how it is divided between intermediate sales to other production sectors and sales to final demand sectors such as households, government, and exports. Table 5 outlines construction of the rows for each HEI.

Table 5. Summary of HEI rows (source: compiled by authors)

\begin{tabular}{|l|l|}
\hline & \multicolumn{1}{|c|}{$\begin{array}{c}\text { Individually determined/Proxied by assuming ratios } \\
\text { for the university sector }\end{array}$} \\
\hline Income from exports & Universities Official Financial Activities Reports \\
\hline Income from Lithuanian government & Universities Official Financial Activities Reports (UOFAR) \\
\hline $\begin{array}{l}\text { Income from other final demand } \\
\text { categories and intermediate demand }\end{array}$ & $\begin{array}{l}\text { Input-Output Table for Lithuania 2010 (last time adjusted } \\
2015)\end{array}$ \\
\hline
\end{tabular}

\section{HEIs' impact on the economy: the case of Lithuania}

Following its independence in 1990, the Baltic state adopted the Law on Research and Higher Education (Republic of Lithuania, 1991), which declared a free higher education to all students in good standing (Thomas, 2001). The move was an attempt to move the country away from its former Soviet influence of command structures and more toward a market economy with a European standard of instruction (Vengris, 1997). Since the introduction of the law in 1991, it has since been amended (Republic of Lithuania, 2009). However, vocational education remains free of charge at public vocational schools in Lithuania (Daniunas et al., 2013). In addition, both fully-funded and partially-funded student slots are available at colleges and universities through a joint admission system that allocates the state-funded scholarships to students according to their academic capabilities (Daniunas et al., 2013).

A few issues that are equally as concerning as the offer of free education, are the structural problems within the HE sector of Lithuania that create uncertainties around future of state-funded higher education. The country's limited educational funding has created uncertainty about the quality of the education delivered at public HEIs. Low salaries of researchers and professors of Lithuanian universities has led to massive emigration of highlyskilled researchers who are unable to support themselves (MacDonald, 2010; Yudkevich et al., 2017). Similarly, the loss of qualified instructors has been followed by an attrition of the country's brightest students, who leave in favour of foreign HEIs and never return home (Daniunas et al., 2013; Herndon, 2008). The loss of talent is further com-pounded by issues with quality control (Legcevic \& Hecimovic, 2016). The Centre for Quality Assurance in Higher Education, the government agency tasked with monitoring educational quality at HEIs, was recognised to have insufficient resources to effectively carry out its functions, leading some citizens to question the value of the qualifications received from public institutions (Thomas, 2001). 
These issues demonstrate a need to understand the economic impact and the value of HEIs on the economy of Lithuania.

Based on the newest OECD (2017) data on Tertiary education in Lithuania, the main issues on strategic perception towards Lithuania's HEIs System distinguished include:

- Despite having one of the highest participation levels in tertiary education, Lithuania's tertiary education is overcoming serious changes due to the large number of comparably small institutions, which cannot reach the efficiency and quality required to compete internationally.

- Although Lithuania's universities provide a significant part of tertiary education and gather around $87 \%$ of all students, they have not reached the satisfactory level of performance in research and development areas compared to universities in other European countries.

- Lithuania faces a challenge in the consolidation of its tertiary education. The resolution of this problem would allow HEIs to increase their efficiency of public resource use, as well as to implement the necessary changes to allow for competition for international funding, researchers and students, because:

- Low student numbers result in inefficiency in use of human (instructor) and physical (facilities) resources.

- Low enrolments pose a threat to the quality of instructional programmes as course offerings and instructor numbers decline, and peer learning weakens.

- Small institution size limits the "critical mass" of researchers, facilities, and research infrastructure needed to perform scientific research at an international level.

- Despite the fact that Lithuania's share of national income (public and private) spent on tertiary institutions is close to international benchmarks (OECD, 2017) and reaches the OECD average, the financial resources received are not used efficiently by institutions to achieve higher quality of instruction and research efficiency level.

This exceptional diversification, taken together with progressively decreasing numbers of students entering Lithuanian HEIs in the environment of higher education reforms, provides sufficient argument to investigate the impacts of all Lithuanian HEIs within a single consolidated framework.

The sample used in the present study consists of data containing information of inputs and outputs at the level of 13 public universities (out of 14) operating in Lithuania and covering the period of 2010-2016. We were not able to gather data for the 2017 because some data sources changed their calculation methodology. Therefore, in order to be able to compare the data between different time periods, we chose to investigate only chosen period.

Public universities examined included small institutions, as well as large classical research universities. In addition, highly-specialised HEIs were also examined. The sample used in the study predominantly consisted of public universities that represent more than $87 \%$ of all students studying in Lithuania's public and private universities (EMIS, 2016). Raw Type II output multipliers of HEIs in Lithuania are represented in Figure 1.

The Input-Output matrix of Lithuania was used for estimation of an impact of High Education to whole country economy. To this end, an Input-Output table (Table 6) of Lithuania's main 11 economic activities according to NACE 2 classification was used: 


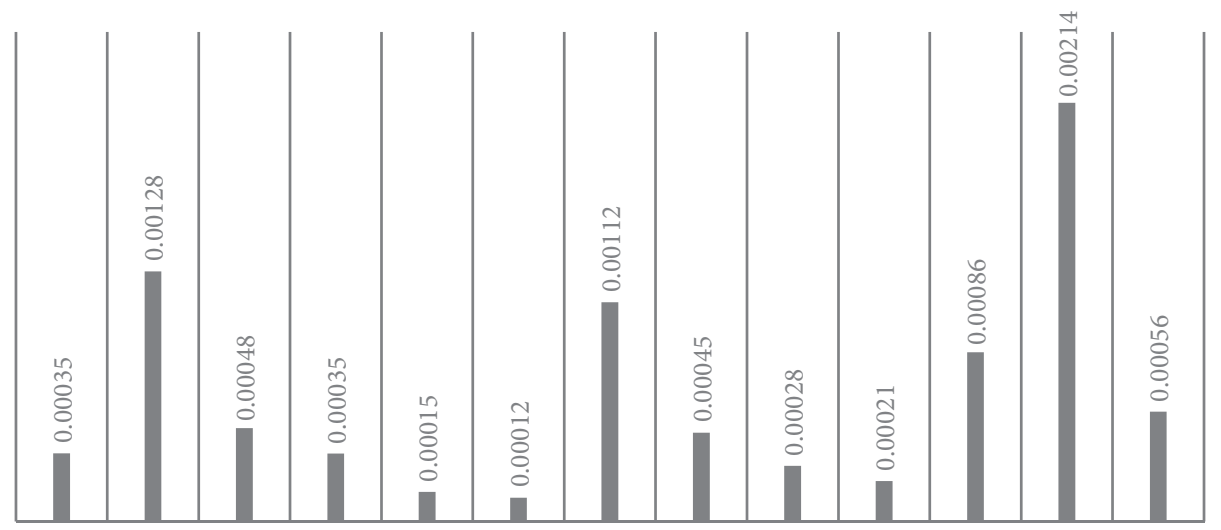

HEI 1 HEI 2 HEI 3 HEI 4 HEI 5 HEI 6 HEI 7 HEI 8 HEI 9 HEI 10 HEI 11 HEI 12 HEI 13

Figure 1. Raw Type II output multipliers of HEIs in Lithuania (source: compiled by authors)

Table 6. Aggregated Input-Output table (source: compiled by authors)

\begin{tabular}{|l|}
\hline A - Agriculture, forestry and fishing \\
\hline $\begin{array}{l}\text { B + C + D + E - Mining and quarrying; manufacturing; electricity, gas, steam and air conditioning } \\
\text { supply; water supply; sewerage, waste management and remediation activities }\end{array}$ \\
\hline C - Manufacturing \\
\hline F - Construction \\
\hline $\begin{array}{l}\text { G + H + I - Wholesale and retail trade; repair of motor vehicles and motorcycles; transportation } \\
\text { and storage; accommodation and food service activities }\end{array}$ \\
\hline J - Information and communication \\
\hline K - Financial and insurance activities \\
\hline L - Real estate activities \\
\hline $\begin{array}{l}\text { M + N - Professional, scientific and technical activities; administrative and support service } \\
\text { activities }\end{array}$ \\
\hline $\begin{array}{l}\text { O + Q - Public administration and defence; compulsory social security; human health and social } \\
\text { work activities }\end{array}$ \\
\hline P - Education \\
\hline R + S + T - Arts, entertainment and recreation, repair of household goods and other services \\
\hline
\end{tabular}

The aim of the present study was to determine the impact of each HEI on the economy of Lithuania. Since information pertaining to HEI was lacking in the Input-Output table, temporary disaggregation methods were applied and different disaggregation methods were engaged. Economic effect multipliers of HEIs were calculated in three different ways (Table 7). 
Table 7. Economic effect multipliers of HEIs calculated in three different ways (source: compiled by authors)

\begin{tabular}{|c|c|c|c|}
\hline $\begin{array}{l}\text { Three different ways of calculating } \\
\text { output multipliers of HEIs, showed } \\
\text { consistency of the data. }\end{array}$ & $\begin{array}{c}\text { Regression } \\
\text { approach (based on } \\
\text { income, number } \\
\text { of students and } \\
\text { number of FTE) }\end{array}$ & $\begin{array}{l}\text { Regression } \\
\text { approach (based on } \\
\text { all variables) }\end{array}$ & $\begin{array}{l}\text { Proportional } \\
\text { approach (based } \\
\text { on expenses) }\end{array}$ \\
\hline $\mathrm{P}-$ Education & 0.041 & 0.041 & 0.041 \\
\hline Pre-primary and primary education & 0.006 & 0.006 & 0.006 \\
\hline Basic and secondary education & 0.015 & 0.015 & 0.015 \\
\hline Colleges & 0.001 & 0.001 & 0.001 \\
\hline Higher Education & 0.008 & 0.008 & 0.008 \\
\hline HEI1 & 0.00035 & 0.00035 & 0.00035 \\
\hline HEI2 & 0.00128 & 0.00130 & 0.00130 \\
\hline HEI3 & 0.00048 & 0.00047 & 0.00047 \\
\hline HEI4 & 0.00035 & 0.00034 & 0.00034 \\
\hline HEI5 & 0.00015 & 0.00015 & 0.00016 \\
\hline HEI6 & 0.00012 & 0.00013 & 0.00013 \\
\hline HEI7 & 0.00112 & 0.00111 & 0.00111 \\
\hline HEI8 & 0.00045 & 0.00046 & 0.00046 \\
\hline HEI9 & 0.00028 & 0.00029 & 0.00028 \\
\hline HEI10 & 0.00021 & 0.00021 & 0.00021 \\
\hline HEI11 & 0.00086 & 0.00086 & 0.00086 \\
\hline HEI12 & 0.00214 & 0.00214 & 0.00214 \\
\hline HEI13 & 0.00056 & 0.00053 & 0.00053 \\
\hline $\begin{array}{l}\text { Research and development in the } \\
\text { field of education; Other matters not } \\
\text { related to education in the group }\end{array}$ & 0.010 & 0.010 & 0.010 \\
\hline
\end{tabular}

Three different temporal disaggregation approaches where applied to calculate HEI impact factors:

1. Proportional approach. This method involves the interpolation of data observed by using a related high-frequency indicator - expenditure of each HEI in Lithuania. The process forces the condition that the sum of the interpolated series must be equal to the initial value of all results pertaining to higher education in an Input-Output table. An expenditure indicator was selected because the volumes of gross value added in education are calculated according to the expenditure approach in Lithuania.

2. Regression approach. The regression model relates the disaggregated series with a set of known high frequency indicators. Two different sets of high frequency data were used: 
- Total income, Number of students and Full time equivalent (staff);

- Income from Lithuanian Government disaggregated by purpose: Exports Income by purpose and Other Income plus Number of students.

In conclusion, we can state that final results do not depend on the chosen method because the biggest difference between methods does not exceed 5\%, which demonstrates the stability and reliability of the results.

The conducted research also has some limitations. Empirical analysis draws on a number of data sources, both primary and secondary. Due to the lack of such a disaggregated database, the task of data collection was extremely challenging. One of the problems associated with data collection was the differences in data collection methods and periods by data sources.

\section{Conclusions}

The present study examines the issues surrounding the expenditure impact of Lithuanian HEIs on the economy of Lithuania by employing an input-output analysis. As such, we have calculated the output for each of the 13 public HEIs in Lithuania, and our findings suggest that Lithuanian HEIs have a significant positive economic impact on the national economy. Moreover, we have found that the I-O model serves as an appropriate tool for assessing the overall impact of HEIs on national economic growth, compared to a pure economic impact analysis.

We demonstrate that the HEIs sector showed on of the highest Type II output multipliers compared to other sectors in Lithuania. This is potentially due to the compensation of employees forming a larger share of expenditure of HEIs, which might be at a higher level in comparison to other industrial sectors. At the institutional level, there seems a clear distinction between bigger and smaller HEIs in terms of their economic impacts. More specifically, HEI2, HEI11 and HEI12 show relatively higher multipliers compared to smaller institutions, such as HEI1 or HEI3. HEI12 demonstrates significantly higher multipliers than the other three biggest HEIs together, suggesting the existence of agglomeration effects. Although for universities such as HEI4, HEI6 or HEI9 the output multiplier effect is minor when compared to HEI12, it still indicates, in the Lithuanian context, that agglomeration plays an important role in explaining spatial variations in the universities' economic impact.

Our study offers valuable insight for stakeholders along the value chain of higher education by revealing HEIs' significant contribution to the economy, as well as value and return on investment. Overall, our findings reveal added output value to the local economy due to HEI activity. Whilst our analysis has the potential to contribute to the current policy debates about higher education in Lithuania, some caveats also need to be stated. Our analysis, while enabling the discussion of the effects of increasing or decreasing exchequer funding to HEIs in the immediate future, does not provide a statement on the effects of that change towards a wider industrial policy. The present study does not address the issues of returnon-investment in education and quality of higher education, the evaluation of which is the matter for a different study. 
The findings of the present study which point out investment inputs into HEIs which have yielded sufficient value to justify a continuance of its funding. Alternatively, study findings that show insufficient value can be used as a justification for discontinuing further investment or consolidating low-value HEIs. Lastly, this study may provide insights that encourage Lithuania's leadership to create additional output streams, which would increase the value the HEIs add to the local economy, either through enhanced specialisation programs, research incentives, job creation, and/or labour income.

Future directions. Despite the considerable degree of certainty regarding the inputs and outputs of each individual HEI, the analysis could be further refined. In particular, it would be of interest to obtain greater depth of information regarding the expenditure on purchased goods and services. Currently, HEIs in Lithuania are undergoing drastic restructuring changes, which will result in merging the 14 existing HEIs to form a total of 9 HEIs. It would be of interest to replicate the present study in the context of the remaining, consolidated HEIs in order to determine their output multiplier effect and their effect on the economy in order to determine wither the new composition of the HE sector in Lithuania will contribute further improvement to the country's economy.

\section{References}

Barra, C., \& Zotti, R. (2017). Investigating the human capital development-growth nexus: does the efficiency of universities matter? International Regional Science Review, 40(6), 638-678. https://doi.org/10.1177/0160017615626215

Beck, R., Elliott, D., Meisel, J., \& Wagner, M. (1995). Economic impact studies of regional public colleges and universities. Growth and Change, 26(2), 245-260. https://doi.org/10.1111/j.1468-2257.1995.tb00170.x

Bonwell, C. C., \& Eison, J. A. (1991). Active learning: creating excitement in the classroom. 1991 ASHEERIC Higher Education Reports. ERIC Clearinghouse on Higher Education, The George Washington University, One Dupont Circle, Suite 630, Washington, DC 20036-1183.

Borralho, C., Feria, I., \& Lopes, S. (2015). The impact of higher education on socioeconomic and development dynamics: lessons from six study cases. Investigaciones de Economía de la Educación 10, 10, 887-905.

Brennan, J., Cochrane, A., Lebeau, Y., \& Williams, R. (2018). Universities, economic development and regeneration. In J. Brennan, A. Cochrane, Y. Lebeau, \& R. Williams (Eds.), The University in its Place (pp. 61-74). Dordrecht: Springer. https://doi.org/10.1007/978-94-024-1296-3_4

Carroll, M. C., \& Smith, B. W. (2006). Estimating the economic impact of universities: the case of Bowling Green State University. The Industrial Geographer, 3(2), 1-12.

Ciccone, A., \& Peri, G. (2006). Identifying human-capital externalities: theory with applications. The Review of Economic Studies, 73(2), 381-412. https://doi.org/10.1111/j.1467-937X.2006.00380.x

Cox, S., \& Taylor, J. (2006). The impact of a business school on regional economic development: a case study. Local Economy, 21(2), 117-135. https://doi.org/10.1080/02690940600608069

Daniunas, A., Kliukas, R., Prentkovskis, O., \& Ulinskaite, D. (2013). The impact of Lithuanian science and study reform on university activities (admission): A case of Vilnius Gediminas Technical University. Procedia - Social and Behavioral Sciences, 93, 565-573. https://doi.org/10.1016/j.sbspro.2013.09.240

Deininger, K., \& Byerlee, D. (2011). The rise of large farms in land abundant countries: Do they have a future? The World Bank. https://doi.org/10.1596/1813-9450-5588 
Drucker, J. (2016). Reconsidering the regional economic development impacts of higher education institutions in the United States. Regional Studies, 50(7), 1185-1202. https://doi.org/10.1080/00343404.2014.986083

Drucker, J., \& Goldstein, H. (2007). Assessing the regional economic development impacts of universities: A review of current approaches. International regional science review, 30(1), 20-46.

Elliott, D. S., Levin, S. L., \& Meisel, J. B. (1988). Measuring the economic impact of institutions of higher education. Research in Higher Education, 28(1), 17-33.

Florax, R. G. M. (1992). The university: a regional booster? Economic impacts of academic knowledge infrastructure. Aldershot, UK: Avebury.

Forrant, R. (2001). Pulling together in Lowell: the university and the regional development process. European Planning Studies, 9(5), 613-628. https://doi.org/10.1080/09654310120057331

Fotea, A. C., \& Gutu, C. (2016). Historical and theoretical framework of the relation between higher education institutions and the process of regional economic development. Entrepreneurial Business and Economics Review, 4(1), 23-42. https://doi.org/10.15678/EBER.2016.040103

Garrido-Yserte, R., \& Gallo-Rivera, M. T. (2010). The impact of the university upon local economy: three methods to estimate demand-side effects. The Annals of Regional Science, 44(1), 39. https://doi.org/10.1007/s00168-008-0243-x

Glasson, M. J., Stapleton, F., Keay, L., Sweeney, D., \& Willcox, M. D. (2003). Differences in clinical parameters and tear film of tolerant and intolerant contact lens wearers. Investigative Ophthalmology \& Visual Science, 44(12), 5116-5124. https://doi.org/10.1167/iovs.03-0685

Goddard, J., \& Vallance, P. (2013). The university and the city. New York: Routledge

Goldstein, H., \& Renault, C. (2004). Contributions of universities to regional economic development: A quasi-experimental approach. Regional Studies, 38(7), 733-746.

https://doi.org/10.1080/0034340042000265232

Guerrero, M., Cunningham, J. A., \& Urbano, D. (2015). Economic impact of entrepreneurial universities' activities: An exploratory study of the United Kingdom. Research Policy, 44(3), 748-764. https://doi.org/10.1016/j.respol.2014.10.008

Harris, R. I. (1997). The impact of the University of Portsmouth on the local economy. Urban Studies, 34(4), 605-626. https://doi.org/10.1080/0042098975943

Hermannsson, K., Lisenkova, K., McGregor, P., \& Swales, J. (2010). An HEI-disaggregated input-output table for Wales. University of Strathclyde Glasgow.

Hermannsson, K., Lisenkova, K., McGregor, P. G., \& Swales, J. K. (2013). The expenditure impacts of individual higher education institutions and their students on the Scottish economy under a regional government budget constraint: homogeneity or heterogeneity? Environment and Planning A: Economy and Space, 45(3), 710-727. https://doi.org/10.1068/a45233

Hermannsson, K., Lisenkova, K., McGregor, P. G., \& Swales. J. K. (2015). The expenditure impacts of London's higher education institutions: the role of diverse income sources. Studies in Higher Education, 40(9), 1641-1659. https://doi.org/10.1080/03075079.2014.899338

Hermannsson, K., \& Swales, K. (2010). Capturing the overall economic impacts of HEIs. Commissioned report.

Herndon, M. C. (2008). The public benefits of higher education: examining the relationship between state spending on higher education and the formation of human capital (Doctoral dissertation). Virginia Tech.

Huggins, R., \& Cooke, P. (1997). The economic impact of Cardiff University: innovation, learning and job generation. GeoJournal, 41(4), 325-337. https://doi.org/10.1023/A:1006863820399

Huggins, R., \& Johnston, A. (2009). The economic and innovation contribution of universities: a regional perspective. Environment and Planning C: Government and Policy, 27(6), 1088-1106. https://doi.org/10.1068/c08125b 
Huggins, R., Johnston, A., \& Thompson, P. (2012). Network capital, social capital and knowledge flow: how the nature of inter-organizational networks impacts on innovation. Industry and Innovation, 19(3), 203-232. https://doi.org/10.1080/13662716.2012.669615

Jaeger, A., \& Kopper, J. (2014). Third mission potential in higher education: measuring the regional focus of different types of HEIs. Review of Regional Research, 34(2), 95-118.

https://doi.org/10.1007/s10037-014-0091-3

Johansen, T., \& Arano, K. (2016). The long-run economic impact of an institution of higher education: Estimating the human capital contribution. Economic Development Quarterly, 30(3), 203-214. https://doi.org/10.1177/0891242416655204

Kaiser, F., Vossensteyn, H., \& Koelman, J. (2001). Public funding of higher education. A comparative study of funding mechanisms in ten countries. Enter for Higher Education Policy Studies, 1-127.

Kotosz, B., Gaunard-Anderson, M. F., \& Lukovics, M. (2018). The local economic impact of universities: an international comparative analysis (France and Hungary). In Entrepreneurship in PostCommunist Countries (pp. 115-131). Cham: Springer. https://doi.org/10.1007/978-3-319-75907-4_8

Legcevic, J., \& Hecimovic, V. (2016). Internal quality assurance at a higher education institution. Business Excellence, 10(2), 75-87.

Leontief, W. W. (1936). Quantitative input and output relations in the economic systems of the United States. The review of economic statistics, 105-125.

Lepori, B., Benninghoff, M., Jonbloed, B., Salerno, C., \& Slipersaeter, S. (2007). Changing models and patterns of higher education funding: Some empirical evidence. In A. Bonaccorsi \& C. Daraio (Eds.), Universities and strategic knowledge creation (pp. 85-111). Cheltenham: Edward Elgar.

MacDonald, J. L. (2010). Lithuanian migration in crisis? A look into the effects of the current economic crisis on migration (Master Thesis). Lund University.

McGregor, P., Swales, K., \& McLellan, D. (2006). The overall impact of higher education institutions on regions: a critical review. Centre for Public Policy for the Regions's Network on the Overall Impact of HEIs on Regional Economies: Final Report, Centre for Public Policy for Regions, Glasgow.

Moretti, E. (2004). Workers' education, spillovers, and productivity: evidence from plant-level production functions. American Economic Review, 94(3), 656-690.

OECD. (2018). How does the earnings advantage of tertiary-educated workers evolve across generations? Education Indicators in Focus, No. 62. OECD Publishing, Paris. https://doi.org/10.1787/3093362c-en

OECD. (2017). Education in Lithuania, reviews of national policies for education. OECD Publishing. https://doi.org/10.1787/9789264281486-en

OECD. (2013). Education at a Glance 2013: OECD Indicators. OECD Publishing. https://doi.org/10.1787/eag-2013-en

Pastor, J. M., Pérez, F., \& De Guevara, J. F. (2013). Measuring the local economic impact of universities: An approach that considers uncertainty. Higher education, 65(5), 539-564. https://doi.org/10.1007/s10734-012-9562-z

Power, D., \& Malmberg, A. (2008). The contribution of universities to innovation and economic development: in what sense a regional problem? Cambridge Journal of Regions, Economy and Society, 1(2), 233-245. https://doi.org/10.1093/cjres/rsn006

Psacharopoulos, G., \& Patrinos, H. (2002). Returns to investment in education: a further update. World Bank Policy Research Working Paper 2881, Washington, DC: The World Bank.

Republic of Lithuania. (1991). Law on higher education and research. Retrieved from https://e-seimas. lrs.lt/portal/legalAct/lt/TAD/TAIS.674/umHBBFNLba

Republic of Lithuania. (2009). Law on higher education and research. Retrieved from https://e-seimas. lrs.lt/portal/legalAct/lt/TAD/TAIS.343430

Siegfried, J. J., Sanderson, A. R., \& McHenry, P. (2007). The economic impact of colleges and universities. Economics of Education Review, 26(5), 546-558. https://doi.org/10.1016/j.econedurev.2006.07.010 
Steinacker, A. (2005). The economic effect of urban colleges on their surrounding communities. Urban Studies, 42(7), 1161-1175. https://doi.org/10.1080/00420980500121335

Stokes, K., \& Coomes, P. (1998). The local economic impact of higher education: An overview of methods and practice. AIR Professional File, 67(6), 1-14.

Thanki, R. (1999). How do we know the value of higher education to regional development? Regional studies, 33(1), 84-94.

Thomas, H. G. (2001). Towards a new higher education law in Lithuania: reflections on the process of policy formulation. Higher Education Policy, 14, 213-223. https://doi.org/10.1016/S0952-8733(01)00015-0

Tilak, J. B. (2018). The Kothari commission and financing of education. In Education and Development in India (pp. 255-282). Palgrave Macmillan, Singapore.

Uyarra, E. (2010). Conceptualizing the regional roles of universities, implications and contradictions. European Planning Studies, 18(8), 1227-1246.

Vengris, S. (1997). External evaluation of studies at Vilnius University, 1994-95. Quality in Higher Education, 3(1), 81-85. https://doi.org/10.1080/1353832960030109

Viaene, J. M., \& Zilcha, I. (2013). Public funding of higher education. Journal of Public Economics, 108, 78-89. https://doi.org/10.1016/j.jpubeco.2013.09.008

World Bank Group. (2016). World Development Report 2016: Digital Dividends. World Bank Publications.

Yen, S. H., Ong, W. L., \& Ooi, K. P. (2015). Income and employment multiplier effects of the Malaysian higher education sector. Margin: The Journal of Applied Economic Research, 9(1), 61-91. https://doi.org/10.1177/0973801014557391

Yudkevich, M., Altbach, P. G., \& Rumbley, L. E. (2017). International faculty in higher education: comparative perspectives on recruitment, integration, and impact. New York, NY: Routledge. https://doi.org/10.4324/9781315543437

Yusuf, S. (2007). University-industry links: policy dimensions. In S. Yusuf \& K. Nabeshima (Eds.), How universities promote economic growth. Washington, DC: World Bank. https://doi.org/10.1596/978-0-8213-6751-3

Zhang, Q., Larkin, C., \& Lucey, B. M. (2017). The economic impact of higher education institutions. In Economic Insights on Higher Education Policy in Ireland (pp. 199-219). Cham: Palgrave Macmillan. https://doi.org/10.1007/978-3-319-48553-9_8

Zhang, Q., Larkin, C., \& Lucey, B. M. (2017). The economic impact of higher education institutions in Ireland: evidence from disaggregated input-output tables. Studies in Higher Education, 42(9), 1601-1623. https://doi.org/10.1080/03075079.2015.1111324 